症 例

\title{
摂食障害を持つ顎変形症患者の手術経験
}

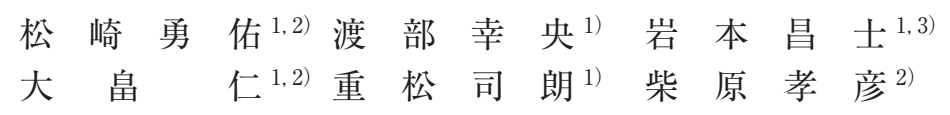

\section{Surgical Experience of Patients with a Jaw Deformity with Eating Disorders}

\author{
Yusuke MATSUZAKI ${ }^{1,2)}$, YUKio WATABE ${ }^{1)}$, MASASHI IWAMOTO ${ }^{1,3)}$, \\ Hitoshi OHATA $^{1,2)}$, SHIRo SHIGEMATSU ${ }^{1)}$ and TAKAHIKo SHIBAHARA ${ }^{2)}$
}

\begin{abstract}
Eating disorder (ED) is a chronic intractable disease that often occurs in adolescent women and exhibits various eating behavioral abnormalities. Such disorders are generally classified into anorexia nervosa, bulimia nervosa or eating disorder not otherwise specified (EDNOS). Their pathogenesis is unknown, but psychological, sociological, and biological factors are thought to contribute to their development. In recent years, the number of patients with eating disorders has risen and the patients are getting younger. We herein report two cases of orthognathic surgery in patients with an eating disorder.

Case 1 received a sagittal split ramus osteotomy for mandibular retrusion with an open bite. The condition was associated with anorexia nervosa, and consultation with internal medicine and psychiatry specialists was required due to the presence of hypothyroidism and liver dysfunction. The patient took a long time until operation,
\end{abstract}

\section{緒 言}

摂食障害者（Eating disorder：以下 ED）は思春期・青年 期の女性に好発し，多彩な食行動異常を呈する原因不明の 慢性難治性疾患である。ED の発症機序は不明であり，心 but there were no adverse events during hospitalization. Case 2 received a sagittal split ramus osteotomy for mandibular protrusion associated with bulimia nervosa and habitual vomiting. Because the patient had a history of psychiatric consultations, a hospital psychiatrist was consulted. Vomiting and sitophobia were not observed during the post-operative intermaxillary fixation period, and the patient was discharged after an uneventful hospitalization. These cases demonstrate the importance of dentists' and medical staff's knowledge of eating disorders and, when performing surgery for patients with ED such as these two cases, providing medical care and treatment according to the condition. It is suggested that treatment should be provided in a facility with respective departments.

Key words: eating disorder (摂食障害), anorexia nervosa（神経性食欲不振症）, bulimia nervosa（神経性 過食症), jaw deformity（顎変形症）

[Received Jan. 18, 2019]

\footnotetext{
1) 東京都立多摩総合医療センター歯科口䏶外科（主任：重松司朗部長）

2) 東京歯科大学口䏶顎顔面外科学講座 (主任 : 柴原孝彦教授)

3) 東京歯科大学口腔病態外科学講座 (主任 : 片倉 朗教授)

1) Department of Dentistry and Oral Surgery, Tokyo Metropolitan Tama Medical Center (Chief: Dr. Shiro SHIGEMATSU)

2) Department of Oral and Maxillofacial Surgery, Tokyo Dental College (Chief: Prof. Takahiko SHIBAHARA)

3) Department of Oral Pathobiological Science and Surgery, Tokyo Dental College (Chief: Prof. Akira KATAKURA)
}

理・社会・生物学的要因の関与が想定されている ${ }^{1-3)}$ ED は神経性食欲不振症（Anorexia nervosa：AN）と神経性過 食症（Bulimia nervosa：BN）抽よび特定不能の摂食障害 (Eating disorder Not Otherwise Specified : 以下 EDNOS) に大別され，その $95 \%$ が女性に発症している ${ }^{4)}$ 。今回， ED を有する 2 例の顎変形症手術治療を経験したので報告する。 


\section{症 例 1}

患者 : 22 歳, 女性。

初診 : 2010 年 9 月。

主訴：反対咬合, 下顎の前突感。

既往歴：高校生時から拒食とともに体重減少がみられ, 甲状腺機能低下, 肝機能異常のため, 某病院内科で神経性 食欲不振症と診断され，神経性食欲不振症による内分泌代 謝異常に対して治療が行われていた。精神科受診歴はな かった。

家族歴：特記事項なし。

現病歴: 某大学歯学部病院で 20 歳時より外科的矯正手 術を前提とした矯正歯科治療を行っていたが，拒食やその 他全身既往により全身麻酔のリスクが高く, 手術困難と説 明された。医科併設の施設での手術を勧められたため, 自
身で近矯正歯科を受診後, 顎変形症手術の相談を目的に当 科を紹介受診した。

\section{現症 :}

全身所見; 身長 $165 \mathrm{~cm}$, 体重 $42 \mathrm{~kg}$, BMI 15.4 で瘦身, 易疲労性であった。初診時, 食事は摂れているとのこと で, 拒食症状はみられなかった。治療途中で転院を余儀な くされたことなどを含め, 治療への不信感や手術への不安 がみられた。

血液検查所見 ; 甲状腺ホルモン T3 0.5ng/dl, ALT 51IU/l, LDH 325IU/1 であった。

口腔外所見；顔貌は左右対称で (Fig. 1A, B), 頭部 X 線規格画像では下顎後退, オトガイ部の高い垂直的高径が みられた（Fig. 2A，B）。

口腔内所見 ; 下顎後退症, 開咬症, 下顎正中は $2 \mathrm{~mm}$ 左 方偏位, overbite $-3.0 \mathrm{~mm}$, overjet $8.0 \mathrm{~mm}$, 術前矯正は ほぼ終了しており，顎関節症状は伴わなかった（Fig. 3)。

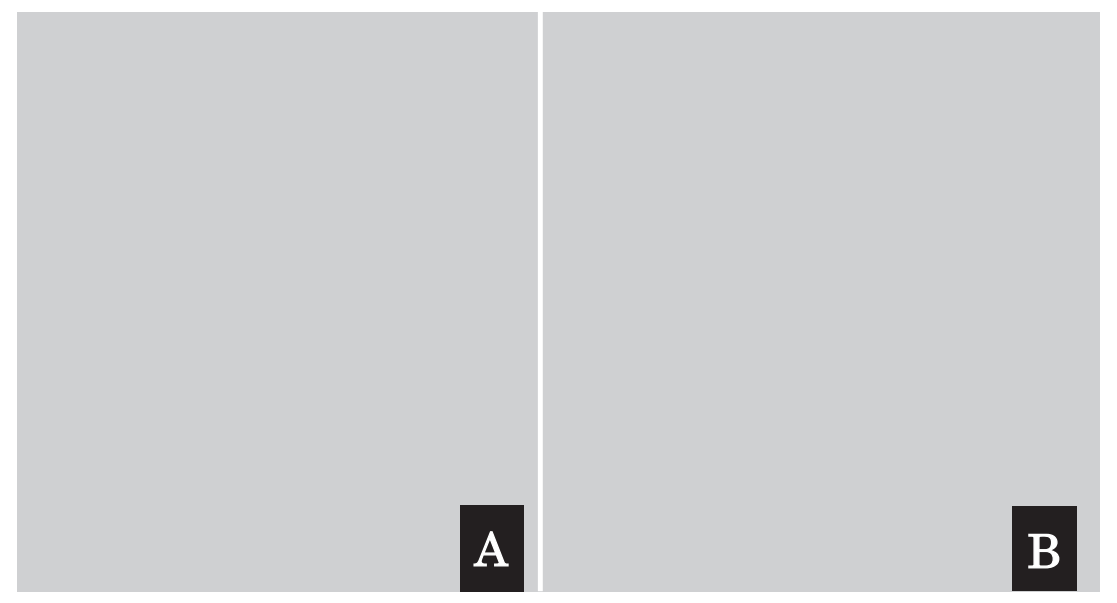

Fig. 1 Images of facial appearance of the case 1 at first visit A : Front, B : Lateral
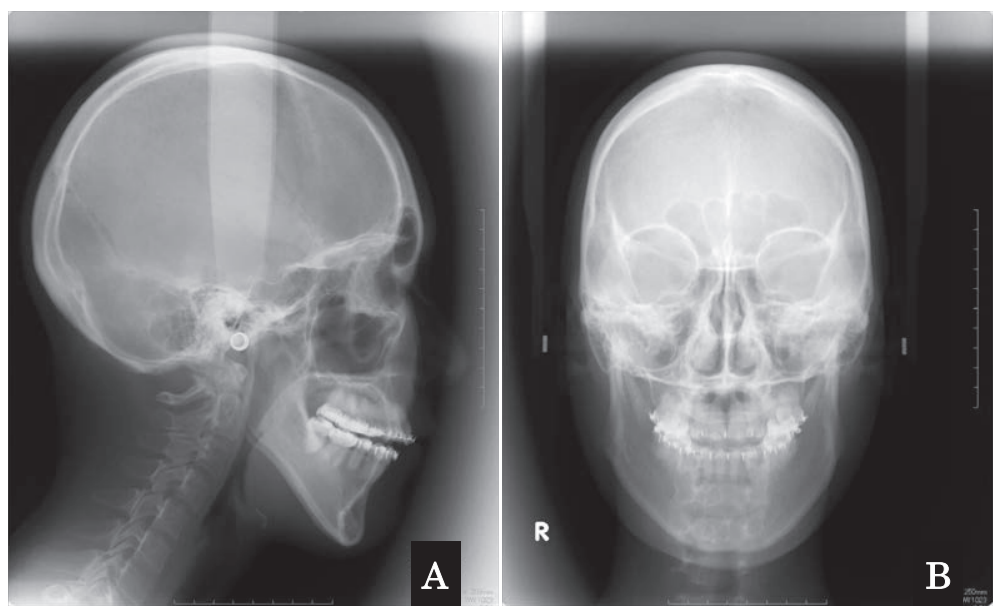

Fig. 2 Radiographic findings of the case 1 at first visit A : Frontal cephalogram, B : Lateral cephalogram 
臨床診断：下顎後退症，開咬症，大オトガイ症。

処置および経過：当科での咬合改善とオトガイ部への手 術希望が強く, 下顎枝矢状分割術, ならびに二次的にオト ガイ形成術を予定した。下顎枝矢状分割術の術前移動量 予測を下顎正中 $2 \mathrm{~mm}$ 右方, 両側臼歯部で $8 \mathrm{~mm}$ 前方, 下 顎前歯部で $8 \mathrm{~mm}$ 前方, 反時計回りに $2 \mathrm{~mm}$ 上方移動と予 測した。オトガイ部は二次的に $5 \mathrm{~mm}$ の中間骨片の中抜き と, 前方へ $7 \mathrm{~mm}$ 水平移動とした。

全身状態の精査・改善のため内科主治医や当院内分泌内 科, 精神科に対診を行い, 甲状腺機能低下症による肝機能 異常に関してはレボチロキシンナトリウム水和物の内服が 開始された。精神科からは, 現在拒食の症状はみられず摂 食状態も良好と思われ，入院中に問題が生じれば介入する との返事を受けた。当科では, 顎矯正手術, 入院中の顎間 固定，食事等について当科の治療方針を詳細に説明し，患 者とのラポール形成を行った。矯正治療の追加と主治医で の肝機能異常 - 甲状腺機能低下に対する治療と栄養指導を 行い, 易疲労性の改善と体重増加を待ってから手術を計 画したために時間を要し, 初診から手術までに約 1 年を要 した。

体重が $46 \mathrm{~kg}$ へと増加し, BMI も 16.9 まで上昇し, 血 液検査所見で甲状腺ホルモン T3 $1.2 \mathrm{ng} / \mathrm{dl}$, ALT 23IU/1, LDH $240 \mathrm{U} / 1$ と甲状腺機能, 肝機能ともに改善し, 全身状 態が改善した。拒食の発現がないことを確認し，2011 年 2 月全身麻酔下に下顎枝矢状分割術を施行した。移動量は 右側で $6 \mathrm{~mm}$, 左側で $9 \mathrm{~mm}$ 前方移動し, 上方へ $3 \mathrm{~mm}$ 反
時計回りに回転移動を行った（Fig. 4A, B）。骨片固定は 両側に 1 枚の 4 穴ストレート型チタンミニプレートおよび 長さ $4 \mathrm{~mm}$ のチタンスクリュー 4 本を用いた。手術時間は 2 時間 15 分, 出血量 $50 \mathrm{ml}$ であった。術後は体調, 精神状 態ともに良好であったため, 翌日よりワイヤーでの䫁間固 定を開始した。なお，ワイヤー固定は前歯部および両側小 臼歯部に 3 か所行い, ワイヤーカッターの常時携帯を指示 した。顎関節位置異常, オトガイ神経麻瘏は認めなかっ た。顎間固定は退院当日までの 12 日間施行したが, 精神 的な落ち込みはなかった。流動食の摂食も問題なく, 体重 の減少もみられず顎間固定解除後に退院した。術後は, 拒 食の発現はなく, 全身状態も良好なことから, 2011 年 11 月に組織内固定装置除去とオトガイ形成術を施行した。中 間骨片を $5 \mathrm{~mm}$ 中抜きし，下方骨片を前方に $5 \mathrm{~mm}$ 水平移 動を行った。手術時間 2 時間 37 分, 出血量 $336 \mathrm{ml}$ であっ た。術後経過は良好で食事は全量摂取できていた。初回手 術より8 年経過しているが後戻りや顎関節異常はみられな い（Fig. 5A, B）。また, 神経性食欲不振症は再燃してい ない。初診時は郵便局でアルバイト勤務をしていたが, 術 後は顔貌, 咬合, 容姿などに満足し, 郵便局の正社員とし て勤務している。

\section{症 例 2}

患者 : 33 歳, 女性。

初診 : 2015 年 8 月。

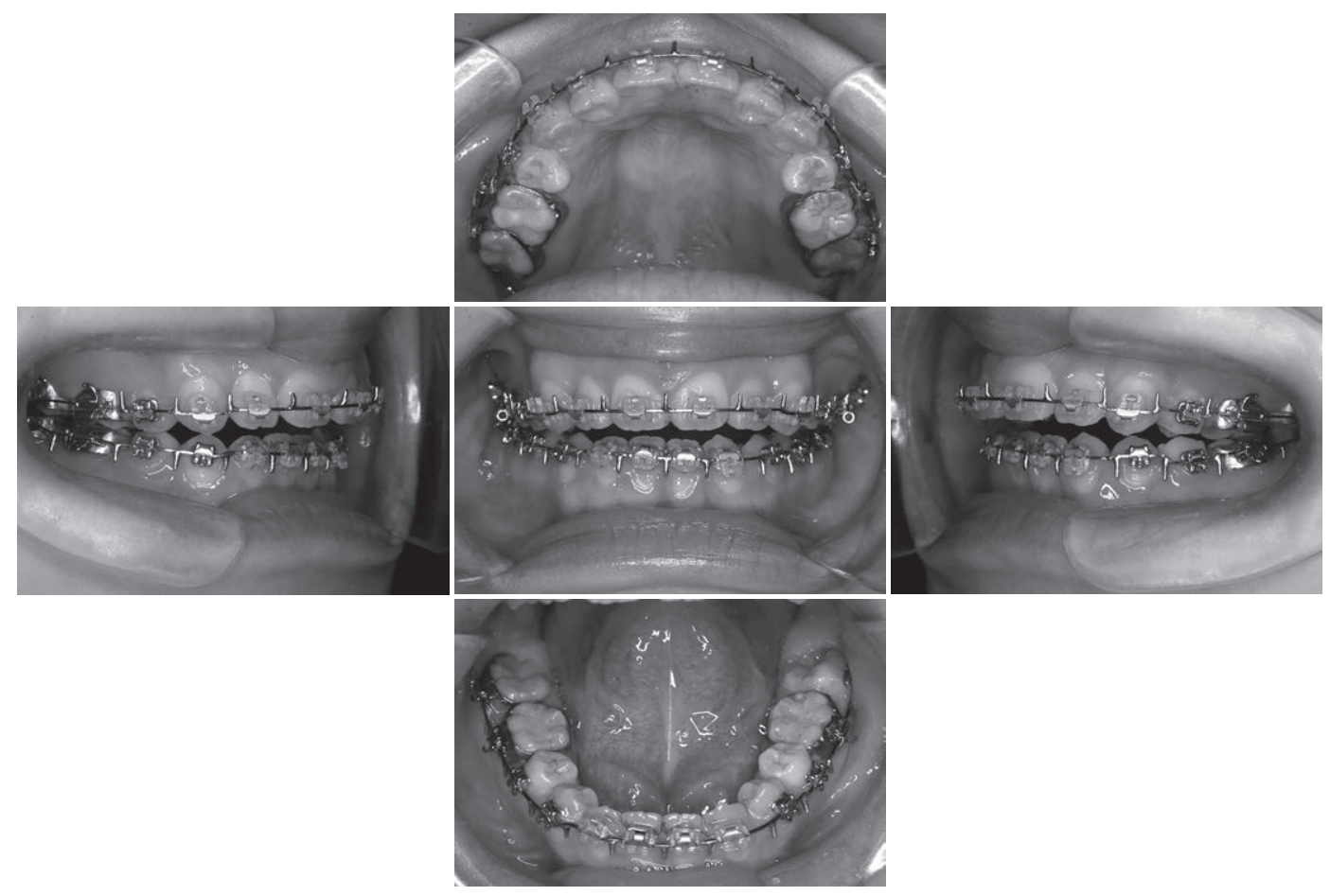

Fig. 3 Intraoral images of the case 1 at first visit 


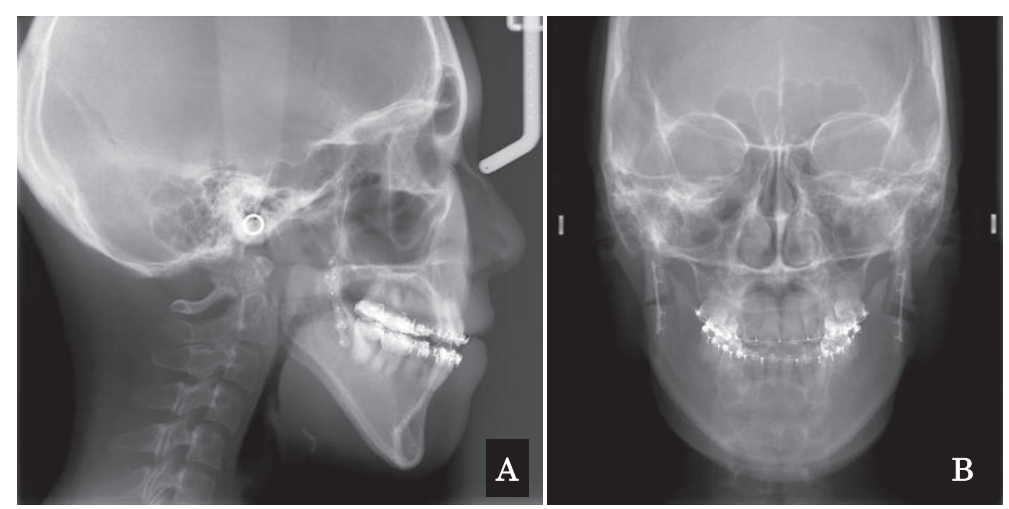

Fig. 4 Post-operative radiographic findings of the case 1 A : Frontal cephalogram, B : Lateral cephalogram

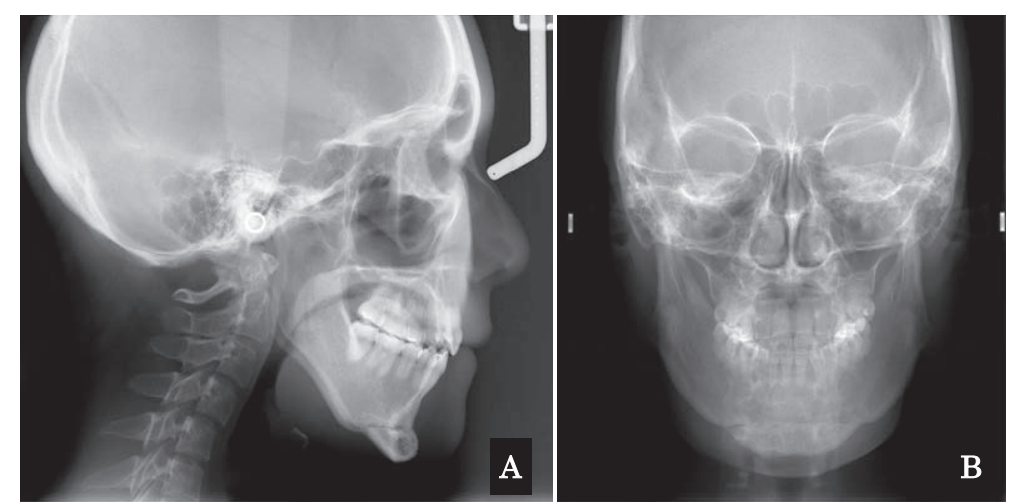

Fig. 5 Radiographic findings of the case 1 at post-genioplasty A : Frontal cephalogram, B : Lateral cephalogram

主訴：下顎の前突感。

既往歴：神経性過食症（むちゃ食い排出型）。2005 年頃 から過食と嘔吐を習慣的に繰り返しており, 少ない時で週 に 3 回, 多い時では毎日, 主に夕食時に過食し嘔吐してい た。過去に精神科受診歴はなく, 心療内科で神経性過食症 と診断され，治療歴があったが， 1 年程前より自己中断し ていた。

家族歴：特記事項なし。

現病歴：下顎の前突感と歯列不正を主訴に近矯正歯科医 院を受診した。顎口腔機能診断で骨格性下顎前突と診断さ れ, 術前矯正に先立ち顎矯正治療前の全身スクリーニング を目的に当科を紹介受診した。

現症 :

全身所見; 身長 $160 \mathrm{~cm}$, 体重 $57 \mathrm{~kg}$, BMI 22.3 と体格中 等度であった。

血液検査所見 ; WBC $3,400 / \mu 1, \mathrm{RBC} 438 \times 10^{4} / \mu \mathrm{l}, \mathrm{Hb}$ $11.5 \mathrm{~g} / \mathrm{dl}, \mathrm{Ht} 36.1 \%, \mathrm{MCV} 82.4 \mathrm{fL}, \mathrm{MCH} 26.3 \mathrm{pg}$ と小球性 貧血がみられた。

口腔外所見；顔貌は正貌非対称で（Fig. 6A, B)，下顎

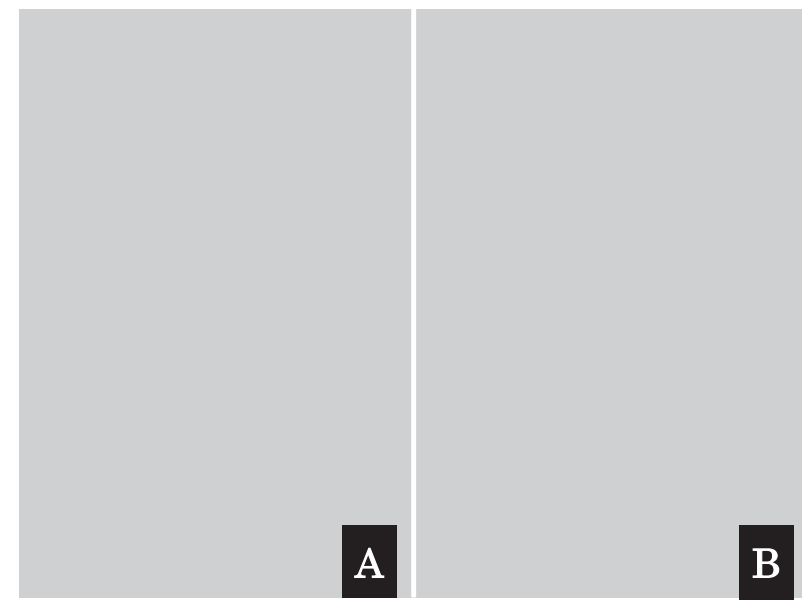

Fig. 6 Images of facial appearance of the case 2 at first visit A : Front, B : Lateral

正中右方偏位がみられた。頭部 X 線規格画像で下顎前突 を認めた（Fig. 7A，B）。

口腔内所見; 下顎前突症, 下顎正中は $2 \mathrm{~mm}$ 右方偏位, 


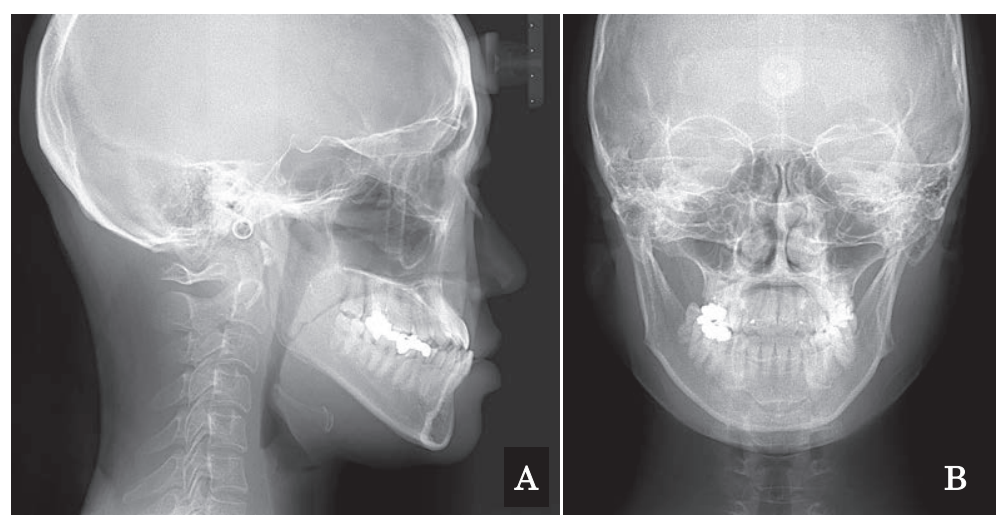

Fig. 7 Radiographic findings of the case 2 at first visit

A : Frontal cephalogram, B : Lateral cephalogram

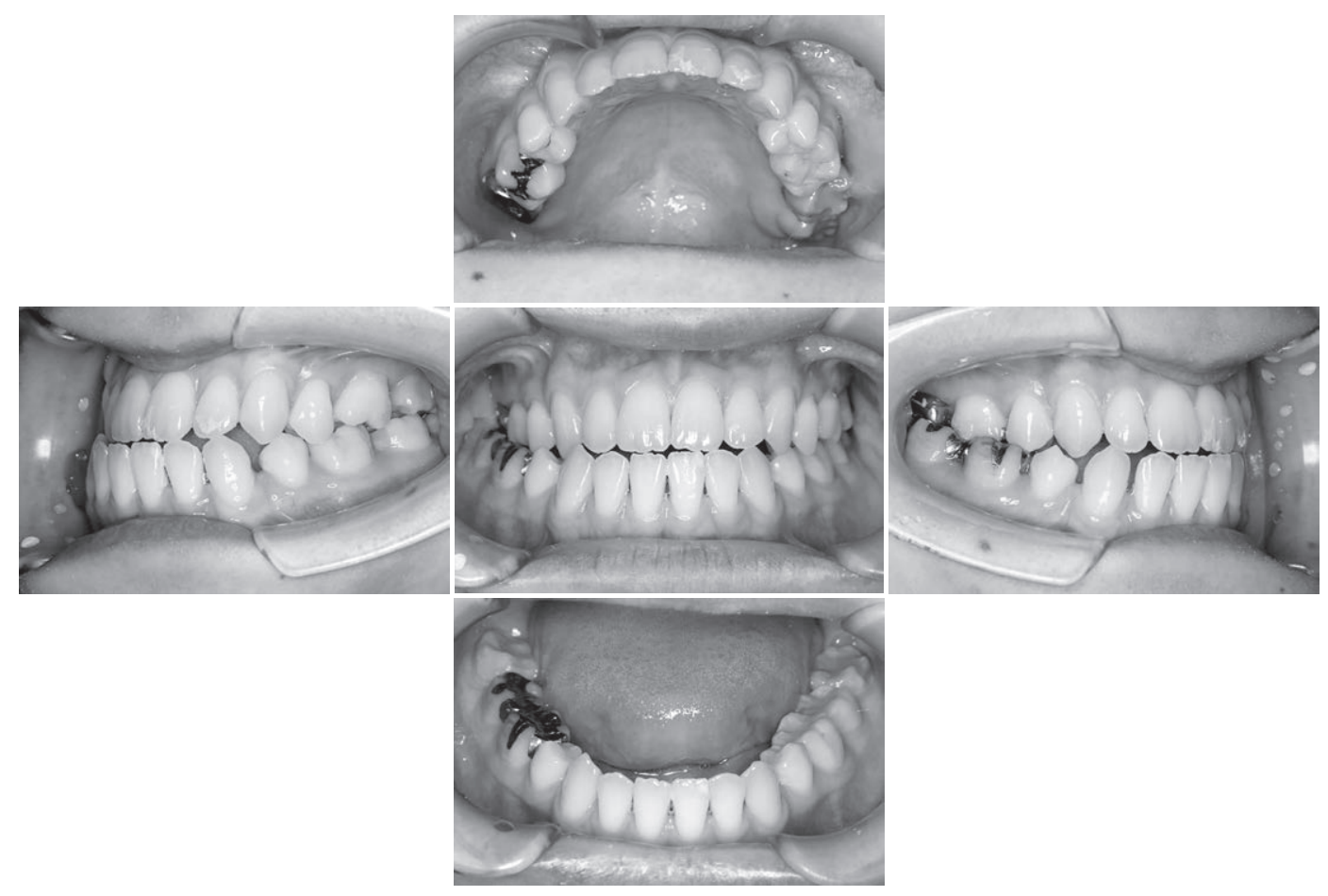

Fig. 8 Intraoral images of the case 2 at first visit

overbite $0 \mathrm{~mm}$, overjet $-1 \mathrm{~mm}$, 顎関節症状は伴わなかっ た (Fig. 8)。

臨床診断：下顎前突症。

処置掞よび経過：当科で術前全身スクリーニング検査と 患者の承諾を得て, 当院精神科へ対診を依頼した。術前の 血液検查で小球性貧血がみられた。心電図検查では異常所 見はみられず，当院精神科からも過食嘔吐はある程度本人 のコントロール下にあり, 入院中の食事コントロールによ りむしろ改善が見込まれるとのことであった。患者には顎 矯正手術, 顎間固定, 予後等を十分に説明した。紹介元の 矯正歯科医には $\mathrm{ED}$ の症状が増悪しなければ手術可能であ
り，術後に嘔吐等の症状により顎間固定ができなかった場 合は顎間ゴムによる開口制限を行う方針であると伝えた。 矯正歯科医と協議した結果, 術前矯正治療を開始すること とした。術前矯正治療終了に伴い当科を再受診し, ED の 症状に増悪が無いことを確認し, 2018 年 2 月全身麻醉下 に下顎枝矢状分割術を施行した。移動量は右側で $4 \mathrm{~mm}$, 左側で $6 \mathrm{~mm}$ 後方移動し，正中を左側へ $2 \mathrm{~mm}$ 移動した (Fig. 9A，B)。骨片固定は両側に 1 枚の 4 穴ストレート型 チタンミニプレートおよび長さ $5 \mathrm{~mm}$ のチタンスクリュー 4 本を用いた。手術時間は 3 時間 15 分, 出血量 $160 \mathrm{ml}$ で あった。術後は体調, 精神状態ともに良好であったため, 


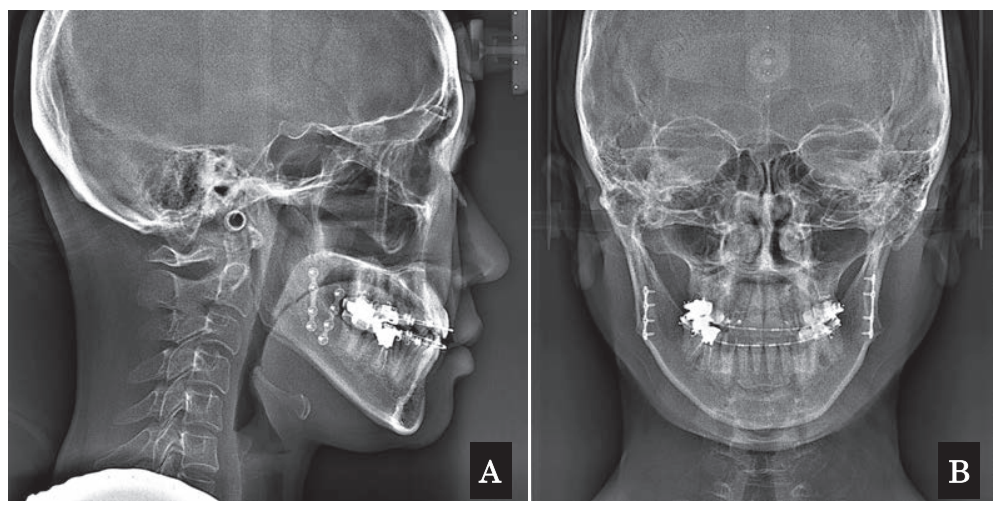

Fig. 9 Post-operative radiographic findings of the case 2

A : Frontal cephalogram, B : Lateral cephalogram

翌日よりワイヤーでの䫣間固定を開始し，退院日までの 14 日間行った。顎間固定開始時に再度, 嘔気・嘔吐によ るリスクを説明し，ワイヤーカッターを常時携帯し気分不 快や嘔吐の際の対処法を指導した。また，担当看護師へも ワイヤーカットの方法を指導し, 患者自らワイヤーカット できなかった場合に対応できるよう準備を行った。流動食 の経口撖取も良好で摂食による自己嘔吐の誘発もなく, 経 過良好で退院した。退院後は過食と習慣性煰吐はみられる が，回数は減少したとのことであった。術後 2 年が経過 し，咬合状態は安定しており，後戻りや顎関節異常はみら れない。現在は仕事に対する意欲も増しており，過食と習 慣性嘔吐の回数は減少し, ED も徐々に改善してきている。

\section{考察}

$\mathrm{ED}$ は思春期・青年期の女性に好発し，わが国では ED 患者の $90 \%$ 以上が思春期・青年期の女性である ${ }^{1)}$ 。 ED は, 多彩な食行動異常を呈する原因不明の慢性難治性疾患であ る $^{2,3)}$ 。ED の発生機序は不明であるが, 家族の状態や両親 の養育態度, 社会環境としてダイエット文化や肥満恐怖と いった現代の社会風潮や文化社会的要因が複雑に関与して いるといわれている3 ${ }^{3,4)}$ 。ED の患者数は年々増加傾向にあ るとともに低年齢化を示している

病状は精神科的問題に加え, 体重変化などに伴う内科 的問題, 無月経など婦人科的問題, 内分泌科的問題をはじ め,ささざまな領域に及ぶ6-9)。このように ED が生命維 持に欠かせない食行動の異常であるがゆえに, その治療も 精神科, 心療内科, 内科, 内分泌科, 婦人科, 歯科などあ らゆる診療科の関与が必要になる ${ }^{10)}$ 。本症例では, 症例 1 では甲状腺機能低下による肝機能異常, 症例 2 では小球性 貧血がみられた。しかし，EDを専門的に診察している施 設は限られており，専門医の数は非常に少ない ${ }^{11)} 。$
$\mathrm{ED}$ と歯科領域の疾患との関連としては, 躈蝕や酸蝕症 があり，その有病率は高いとされている12,13)。BNでは過 食，嘔吐などにより齸蝕がみられる。また，自己誘発性嘔 吐の常習者では唾液腺の腫脹が見られることがある ${ }^{12,14) 。}$ さらに器具や手指を用いての嘔吐では顎関節症のリスクが 高いと言われている ${ }^{15)}$ 。また, 自己誘発性嘔吐は器具など を用いずに誘発されることもあるので，顎矯正手術術後の 顎間固定中の嘔吐による気道閉塞の危険性がある。本症例 では本人へ顎間固定中の嘔吐による気道閉塞の危険性と固 定解除の方法について指導し, 病棟スタッフとの綿密な連 携を行ったが, 習慣性嘔吐が頻繁にみられる場合や術後顎 間固定の固定解除が頻回な場合には顎間ゴムでの下顎牽引 も考慮される。矯正治療では, 矯正装置の脱離による治療 の中断や顎矯正手術の延期などがおこる。ANにおいても $\mathrm{BN}$ 一と病態が変化することが知られており ${ }^{16)}$ ，いずれの 病態においても上記の様な症状を呈する可能性があるとい える。

術前においては，EDの病態抢よび病状の把握が肝要で あり, 予備力の低下が見られる場合には全身麻酔下での手 術が困難となることも予想され, 矯正歯科医と治療計画に ついて密接な情報交換が必須である。

$\mathrm{ED}$ 患者の増加に伴い, 今後 $\mathrm{ED}$ を伴う顎矯正手術患者 は増加するものと思われる。前述のように $\mathrm{ED}$ 患者は精神 科的, 内科的問題を併発している可能性が高く, 安全な周 術期管理が困難となることが予想される。しかし， ED は 一般に認知度が低く, 患者本人が自覚していない場合もあ る。われわれが涉猟しえた限りでは，顎矯正手術を契機に $\mathrm{ED}$ が発症したという報告はなかった。

潜在的な ED をスクリーニングすることは困難であり， 矯正歯科受診時の医療面接が重要である。また，外科的矯 正治療適応症例の場合には術前矯正治療前に連携病院での 診察，全身スクリーニング検査を行うことが望ましい。当 院では, 術前矯正治療前に紹介を受け，全身スクリーニン 
Table 1 The adverse event that is expected for the perioperative period

\begin{tabular}{|c|c|c|c|}
\hline Before operation & During operation & After operation : During IMF & After operation : After ENT \\
\hline Anemia & $\begin{array}{l}\text { Abnormal fracture due to } \\
\text { decreased bone quantity }\end{array}$ & Airway obstruction due to vomiting & $\begin{array}{l}\text { Dissatisfaction to a countenance } \\
\text { after the treatment }\end{array}$ \\
\hline Low body weight & Abnormal bleeding due & $\begin{array}{l}\text { Vulnerary deficiency and infection } \\
\text { due to the undernutrition }\end{array}$ & Exacerbation of the TMD \\
\hline Malnutrition & $\begin{array}{l}\text { to coagulation factor } \\
\text { abnormality }\end{array}$ & Ileus & \\
\hline ECG abnormality & & & \\
\hline Electrolyte abnormalit & & & \\
\hline Amenorrhea (female) & & & \\
\hline
\end{tabular}

グ検査等を実施してから術前矯正治療を開始するように連 携医と相談して診療手順を定めている。全身スクリーニン グ検査で低体重, 内分泌異常がみられれば ED を疑い生活 習慣のより詳細な問診, 診療各科に対診を依頼するべきで ある。また，患者には初診時から手術について詳細に説明 を行っている。顎矯正手術の特性から, 術前矯正期間中に 病態の変化をきたす可能性もあるので術前矯正終了時点で 再評価し, 手術が施行できない可能性もあることを事前に 説明しておく必要がある。いずれにおいても，EDの治療 と並行して顎矯正治療を行わなくてはならないため, 患者 の理解と協力が健常者に比べより重要になる。そのため患 者の治療コンプライアンスによっては, 顎矯正治療を回避 しなければならない可能性もある。

健常人であっても, 顎矯正術後は顎間固定や食形態の変 化などにより食行動が変化しやすい。顎矯正手術を契機と した ED 発症の報告はないが, 重篤な内分泌異常, 電解質 異常がみられない症例で重度神経性食欲不振症患者の顎矯 正手術例が報告されており ${ }^{17)}, 1$ 週間程度の下顎のゴム牽 引と創部ドレン留置期間中の鎮静下で管理を行ったとの報 告をしている。本症例では 2 例とも顎間固定期間は約 10 日間とした。これについては, 術後の後戻りのリスクも考 慮した上で, 本人および精神科と相談し, 当科の通法通り の固定期間を設定することとした。口腔外科医, 病棟ス タッフの厳重な観察と精神科との密な連携を図りながら, 精神状態確認後に顎間固定を行ったが, ともに有害事象な く経過良好で退院することができた。

$\mathrm{ED}$ 患者に関して周術期管理におけるガイドライン等は なく, そのような患者に対する顎矯正治療の可否は定まっ ていない。ANでは徐脈, 浮腫, 低血圧, 低体温, 無月経, 白血球減少などの症状がみられることもあり ${ }^{14)}$, 周術期に おいて管理上問題となる（Table 1)。全身麻酔における手 術適応については, 低血糖, 白血球減少, 心臓合併症, 低 栄養などが無いことが挙げられている18)。

顎矯正治療が ED に及ぼす影響について論じられた報告
はない。伊藤ら ${ }^{19)}$ は, 顎変形症患者は一般的に顔貌変形 に対して強い劣等感は持たず，自尊心は高く保たれている としているが, 一方で高橋ら ${ }^{20)}$ は, 外科的矯正治療に対 して機能的改善を望む大部分の患者が審美的改善を望み, 審美的改善は最も重要な治療動機であると考察している。 $\mathrm{ED}$ をもつ顎変形症患者は特にその傾向が強いものと思わ れる。ED と醜形恐怖症との関連についての報告では, 醜 形恐怖症治療が ED の改善に寄与する可能性について述べ られている21,22)。また, 腹部脂肪吸引術や豊胸手術といっ た美容整形手術が ED の症状改善に寄与するとの報告がみ られる23,24) 一方で, 口腔内および美容皮膚科的な手術を 5 年以内に行った患者で ED の発症リスクが上昇するとし た報告も見られた ${ }^{25)}$ 。患者にとって顎矯正手術による審美 的, 機能的変化が心理面において QOL の向上につながれ ば ED の改善に寄与する可能性もあるが, 逆に不満を抱い た場合には ED の増悪または発症リスクを高めてしまう危 険性がある。術前の手術説明では術後の顔貌の変化や顔貌 の予測の限界について詳細に説明し理解を得る必要があ る。本症例では術後に仕事に意欲的になるなど精神面の改 善がみられ，EDの症状は改善している。手術を施行した ことが良い方向に向かったと思われる。

ED 患者は日本ではまだ一般的に認知されていない。し たがって専門的に加療を行っている施設が極めて少なく, 症状に応じて医科診療各科が対応しているのが現状である。 $\mathrm{ED}$ は拒食症, 過食症など, その病態は多様であり, 症状 に応じて各診療科での対応が必須であり, さらには医師, 歯科医師, 看護師, 心理療法士, ソーシャルワーカー, 栄 養士といった多職種のチーム医療が必要となる ${ }^{13)} 。$

本症例のような $\mathrm{ED}$ を持つ顎変形症患者の顎矯正手術を 行う場合は, 種々の合併症状に対して術前および周術期に 専門医と綿密に連携を図ることは必須であると考えられ る。そのため, 病態に応じた診療が可能な医科診療各科を 併設した施設で治療を行う方が望ましいと思われた。 
著者全員および所属に本論文に関し開示すべき利益相反（COI） はない。

\section{文献}

1）石川俊男, 他：摂食障害の診断と治療 ガイドライ ン, マイライフ社, 東京, 2005, p1-95.

2）石川俊男, 他 : 摂食障害の治療・研究の最近動向につ いて。 心身医，54：122-127，2014.

3）中井義勝，他：摂食障害の臨床像についての全国調 査. 心身医，42：729-737，2002.

4) 中井義勝 : 摂食障害の疫学. 医学のあゆみ, 9:671$675,2012$.

5）傳田健三，他：若年発症の攝食障害に関する臨床的研 究. 児童青年精神医学とその近接領域, $43: 30-56$, 2002.

6) American Psychiatric Association: Diagnostic and Statistical Manual of Mental Disorders, Fourth Edition（DSM-5)．2013．高橋三郎，他監訳：DSM-5 精神疾患の診断・統計マニュアル, 医学書院, 東京, 2014, p53-64, p332-338.

7）鈴木眞由，他：摂食障害の合併症と治療。日心療内 誌, $14: 23-28,2010$.

8）横山祐子, 他：摂食障害. 日心療内誌， 15：179-185, 2011.

9) Hailer, E.: Eating disorders. A review and update. West J Med, 157 : 658-662, 1992

10）永田利彦，他：摂食障害のクリニカルパス。臨床精神 医学, 37：1439-1446, 2008.

11）石井俊男：摂食障害との出会い一昨日, 今日, そして 明日へ向けて一。心身医，55：321-331，2015.

12）井上裕之, 他：摂食障害患者のう蝕罹患状況とその考 察. IRYO, $57:$ 100-107, 2003.

13）西園マー八文：摂食障害の病態理解と治療：精神科医 に求められている対応は何か。精神経誌, 111：854$858,2009$.

14）鈴木眞理：摂食障害一食べられない，あるいは，食べ 過ぎてしまう病気. 日本調理学会誌, $45: 372-377$,
2012

15) Johansson, A.K., et al.: Eating disorders and signs and symptoms of temporomandibular disorders: a matched casecontrol study. Swed Dent J, 34 : 139147,2010

16) Nishimura, H., et al.: Psychological and weight-related characteristics of patients with anorexia nervosarestricting type who later develop bulimia nervosa. Bio Psycho Social Medicine, 2 : 5, 2008.

17）平沼克洋，他：重度神経性食欲不振症患者の下顎骨切 り術における周術期管理経験. 日歯麻誌，45：205207, 2017.

18) Hirose, K., et al.: Perioperative management of severe anorexia nervosa. Br J Anaesth, 112 : 246254,2014

19）伊藤亜希，他：顎変形症患者の人格特性 MMPI, 自 尊心尺度を用いた分析。日顎変形誌， $17: 229-237$, 2007.

20）高橋庄二郎：顔の心理学 一心理学的観点からみた顎 矯正外科一。歯科学報, $100: 643-681,2000$.

21) Rabe-Jablonska Jolanta, J., et al.: The links between body dysmorphic disorder and eating disorders. Eur Psychiatry, $15:$ 302-305, 2000.

22) Hartmann, A.S., et al.: The relationship between anorexia nervosa and body dysmorphic disorder. Clin Psychol Rev, 33 : 675-685, 2013.

23) Saariniemi, K.M., et al.: Does Liposuction Improve Body Image and Symptoms of Eating Disorders?. Plast Reconstr Surg Glob Open, 10 : 461, 2015.

24) Saariniemi, K.M., et al.: The effects of aesthetic breast augmentation on quality of life, psychological distress, and eating disorder symptoms: a prospective study. Aesthetic Plast Surg, 36 : 10901095, 2012.

25) Bachar, E., et al.: Surgery and parental separation as potential risk factors for abnormal eating attitudeslongitudinal study. Eur Eat Disord Rev, 16 : 442-450, 2008. 